\title{
Solid Phase Synthesis
}

\author{
Angus R. Brown ${ }^{a^{*}}$, Pedro H.H. Hermkens ${ }^{\mathrm{b}}$, Harry C.J. Ottenheijm ${ }^{\mathrm{b}}$, David C. Rees ${ }^{\mathrm{a}}$ \\ a Scientific Development Group, Organon Laboratories Ltd., Newhouse, Lanarkshire ML1 5SH, Scotland, UK \\ ${ }^{\mathrm{b}}$ Scientific Development Group, NV Organon, PO Box 20, 5340 BH Oss, The Netherlands \\ Received 5 March 1998
}

\begin{abstract}
Solid phase synthesis is a rapidly expanding area of synthetic chemistry which has been concerned with the synthesis of diverse collections of "drug-like" molecules for use in the drug discovery process. The aim of this review is to introduce the basic concepts and practices of solid phase synthesis to the synthetic chemist. This includes choice of support, linker, development of the synthetic route, reaction monitoring and basic experimental aspects for carrying out reactions on the solid phase. These points are illustrated with the aid of some recent examples from the literature.
\end{abstract}

1. Introduction

2. Solid Phase Synthesis

3. Planning a Solid Phase Synthesis

3.1 The Resin

3.2 The Linker

3.3 Reaction Monitoring

3.4 Experimental Conditions

3.5 Purification

3.6 Automation

4. Recent Examples

\section{Introduction}

The widespread use of polypeptide ${ }^{1}$ and oligonucleotide ${ }^{2}$ synthesis highlights the benefits of carrying out a series of high yielding reactions whilst the target molecule remains tethered to an insoluble (filterable) solid support. ${ }^{3}$ More recently this methodology has been adopted for the synthesis of small organic molecules, ${ }^{4}$ and currently there is a growing number of classical organic reactions which have been successfully translated from solution onto the solid phase. ${ }^{5}$

\section{Solid Phase Synthesis}

To date, the main use of this small molecule chemistry has been directed towards high speed synthesis and biological screening of diverse libraries as part of the drug discovery process. ${ }^{6}$ The widespread use of solid phase synthesis is due to a large extent to the ease of manipulation when compared with classical techniques. Using a mixture of standard laboratory apparatus and inexpensive, readily available, scientific equipment ${ }^{7}$ it is possible to carry out a range of synthetic manipulations with little or no outlay required for ancillary equipment. This can increase the productivity of an experimentalist several fold and can also allow the isolation of multimilligram amounts of product after cleavage from the solid support and purification.

Solid phase routes often allow the use of excess reagents to force reactions to completion. Other benefits often quoted when compared to solution phase methods are the ease of isolation at each step by simple filtration, the ease of automation and also the pseudo dilution effect ${ }^{8}$ which can be synthetically useful in crosslinking or cyclisation reactions.

The main disadvantages of solid phase chemistry are the extra labour required to develop a solid phase route, the limitations of the current range of commercially available supports and linkers as well as the limited means of monitoring reactions in real time. Solid phase routes also necessitate additional steps to link and cleave to and from the support and are generally used to prepare $<100 \mathrm{mg}$ final product.

\section{Planning a Solid Phase Synthesis}

The execution of a solid phase synthesis requires some preparation and decisions to be made. The following stepwise approach might be helpful in this; each step is discussed briefly in the following paragraphs.

- 1: The resin

- 2: The linker; cleavage conditions, site of attachment at target molecule, traceless linkers

- 3: Reaction monitoring

- 4: Experimental conditions; vessels, washing, from solution phase to solid phase

- 5: Purification

- 6: Automation; (i) optimisation and scope determination (ii) equipment

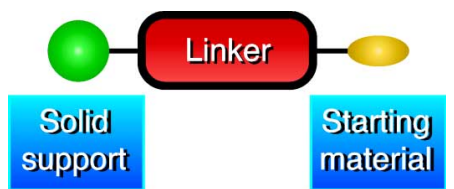

Scheme 1

\subsection{The Resin}

Typical small molecule synthesis is routinely carried out by immobilising a starting material (scheme 1) to the solid support. To date, the majority of published solid phase organic synthesis has been carried out on two main types of solid support (table 1).

The development of solid phase chemistry begins not only with the choice of support and linker, but also with a study of the proposed site of attachment to the target molecules. When the target molecule contains typical linking functionalities such as carboxylic acids, amides or alcohols, there is a range of commercially available resins ${ }^{9}$ which have been reported for the immobilisation. However, the physical/chemical compatibility of resins, linkers and reagents used can be a strong 
Table 1

\begin{tabular}{|c|c|c|c|c|}
\hline Solid support & $\begin{array}{l}\text { Commercially available } \\
\text { functionalities }\end{array}$ & $\begin{array}{l}\text { Particle } \\
\text { Size }\end{array}$ & Functionality & $\begin{array}{c}\text { Chemical } \\
\text { Compatibility }\end{array}$ \\
\hline $\begin{array}{l}\text { Polystyrene- } \\
\text { divinylbenzene } \\
\text { (PS-DVB) } \\
\text { copolymer }\end{array}$ & 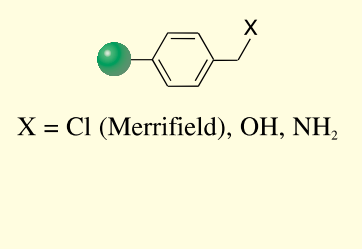 & $\begin{array}{c}100-200 \\
\text { mesh } \\
(75-15-\mu \mathrm{m}) \\
\\
200-400 \\
\text { mesh } \\
(38-75 \mathrm{~mm})\end{array}$ & $\begin{array}{c}0.5 \text { to } 4.0 \\
\mathrm{mmol} / \mathrm{g}\end{array}$ & $\begin{array}{l}\text { Swells in DMF, DCM, } \\
\text { THF, Toluene, } \\
\text { Thermally stable }\end{array}$ \\
\hline $\begin{array}{l}\text { Polyethylene } \\
\text { glycol-PEG } \\
\text { PS-DVB } \\
\text { copolymer }\end{array}$ & $\begin{array}{l}-\left(\mathrm{CH}_{2}\right)_{\mathrm{m}}-\left(\mathrm{OCH}_{2} \mathrm{CH}_{2}\right)_{\mathrm{n}}-\mathrm{OCH}_{2} \mathrm{CH}_{2}-\mathrm{X} \\
\mathrm{X}=\mathrm{Br}, \mathrm{OH}, \mathrm{NH}_{2}, \mathrm{SH}, \mathrm{COOH}\end{array}$ & various & $\begin{array}{c}0.2 \text { to } 0.5 \\
\mathrm{mmol} / \mathrm{g}\end{array}$ & $\begin{array}{l}\text { Swells in both protic and } \\
\text { aprotic solvents }\end{array}$ \\
\hline
\end{tabular}

determining factor in the successful outcome of a solid phase route. For example, PS-DVB is not a suitable solvent for use with aqueous solvent and Ellman et al found that during the synthesis of $\beta$-turn mimetics reduction of a resin bound disulfide was only possible when utilising TentaGel resin (scheme 2 ). ${ }^{10}$ Similarly Hauske et al report difficulties in performing a macrocyclisation Heck reaction using aqueous DMF on polystyrene based resin, but encountered no such difficulty with TentaGel (scheme 3 ). ${ }^{11}$

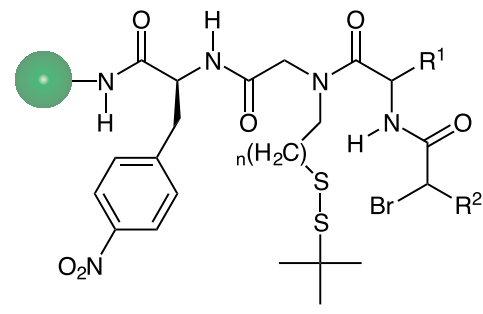

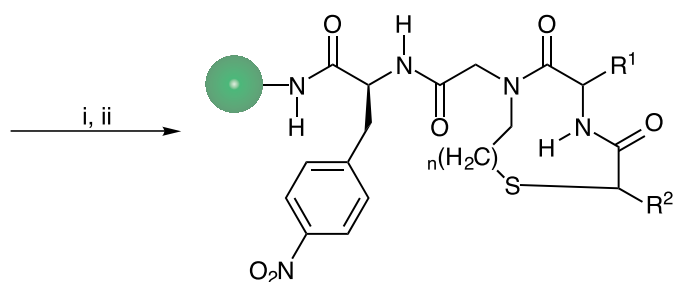

Scheme 2. i) Tributylphosphine/DMF/propanol/water

ii) Tetramethylguanidine

Typically PS-DVB resins do not swell sufficiently in these aqueous mixtures to allow diffusion of reagents into the polystyrene matrix. PEG-PS-DVB co-polymers on the other hand show good swelling properties in polar solvents and hence can give very different results when using identical conditions.

\subsection{The Linker}

Solid phase synthesis requires a covalent linker group, sometimes referred to as a 'handle', to attach the small molecule onto the polymeric resin. This linker bears many similarities to protecting groups in solution phase synthesis inasmuch as it needs to be stable to the reaction conditions used during the elaboration of the small molecule but it needs to be cleaved selectively at the end of the synthesis thus releasing the small molecule from the resin into solution. It should be noted that compared to solution phase synthesis this requirement for a linker often<smiles>C=CC(=O)NCCCCC(NC(=O)C1CCCN1C(=O)c1ccc(I)cc1)C(=O)NCCCNC(=O)OOc1ccccc1</smiles>

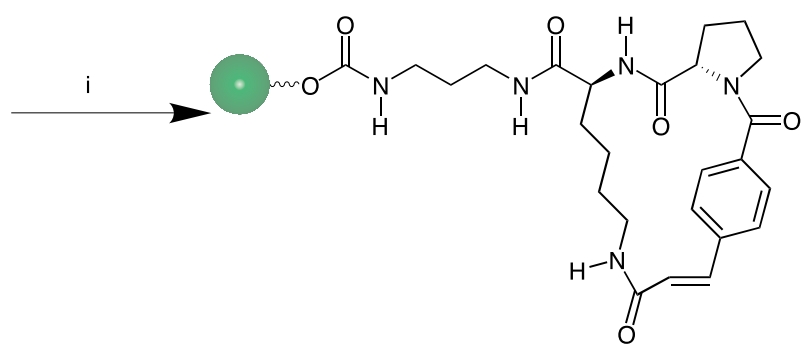

Scheme 3. i) $\mathrm{Pd}(\mathrm{OAc})_{2}, \mathrm{PPh}_{3}, \mathrm{DMF}, \mathrm{H}_{2} \mathrm{O}, \mathrm{Et}_{3} \mathrm{~N}$

adds two additional synthetic steps to a solid phase route. Properties of a linker which may assist solid phase synthesis are given in figure 1.

- Stable to the reaction conditions required for synthesis

- Cleaved selectively at the end of synthesis

- Re-useable

- Facilitate reaction monitoring

- Sequential / Partial release

- Asymmetric induction

Figure 1

Historically, classical solid phase peptide synthesis ${ }^{12}$ made use of an ester group as a linker stable to peptide coupling conditions but cleaved by acid promoted hydrolysis thus liberating a carboxylic acid (Scheme 4). The very strong acid (HF) required to cleave a Merrifield type benzylic ester can be attenuated by using a $\mathrm{Wang}^{13}$ (50\% TFA) or Sasrin $^{14}$ (1\% TFA) linker. 

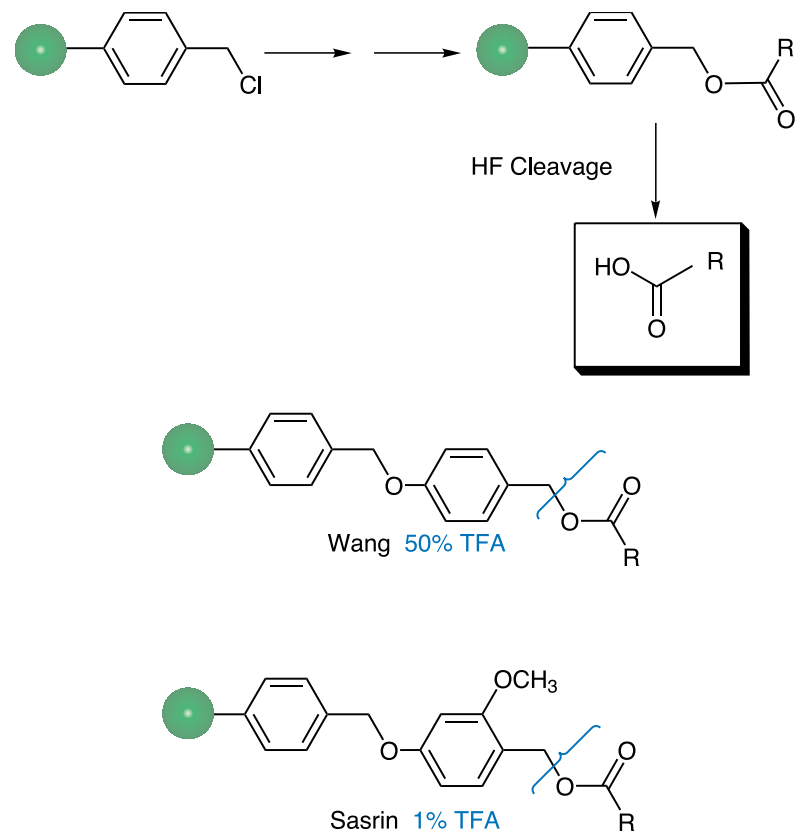

Scheme 4

The growing desire to synthesise increasingly diverse, non-peptide small molecules has led to a requirement for linkers which do not necessarily lead to a polar carboxylic acid group upon cleavage. Currently, a wide variety of linkers exist, many of which are based upon chemistry originally developed for oligomeric Solid Phase Synthesis. The selection of the most appropriate linker for a particular class of target molecule is a key factor in designing a solid phase synthesis. A summary of some of the different types of linkers/cleavages is shown in figure 2. Some specific examples are given below.

- Cyclative cleavage

- Linkers which release specific functional groups

- $\quad$ Traceless linkers (form a C-H bond)

- $\quad$ Activate-able linkers (safety catch)

- Cleavable plus functional group interconversion

- Linkers developed for stability/selectivity

- Re-useable/Recyclable linkers

\section{Figure 2}

Cyclative cleavage ${ }^{15}$ has been used to prepare a variety of 5, 6 and 7 membered (heterocyclic) rings by cyclisation and concomitant cleavage from the resin (scheme 5).

Cyclative cleavage via ruthenium catalysed olefin metathesis has also been reported by several groups. ${ }^{16}$ This method can be used to generate cyclic olefins or olefinic $\mathrm{C}-\mathrm{H}$ bonds in the cleaved product (scheme 6).

Photochemically cleavable linkers such as the o-nitro-benzyl ether group (scheme 7$)^{17}$ are stable to a wide variety of reaction condition whilst allowing particularly selective cleavage conditions illustrate stable linkers which can be cleaved using mild reaction conditions.

Linkers which form an unfunctionalised $\mathrm{C}-\mathrm{H}$ bond upon cleavage are sometimes referred to as "traceless linkers" and a prototype example based upon cleavage of a C-Si bond is shown in scheme $8 .^{18}$
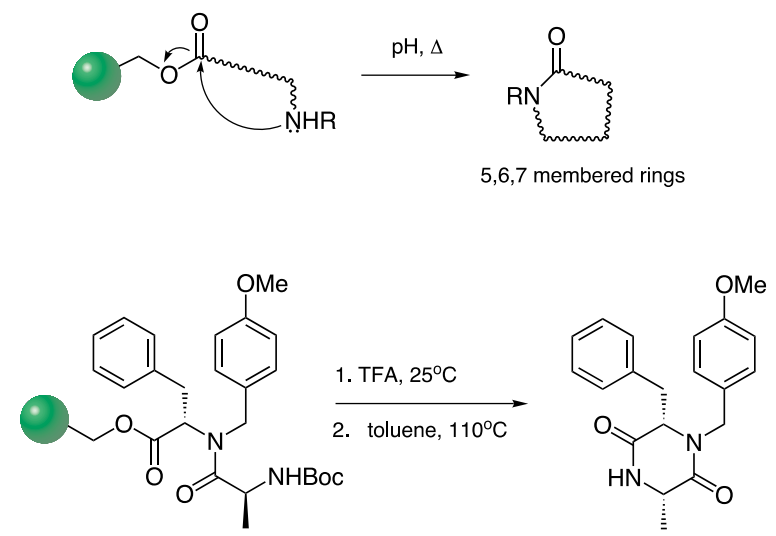

Scheme 5

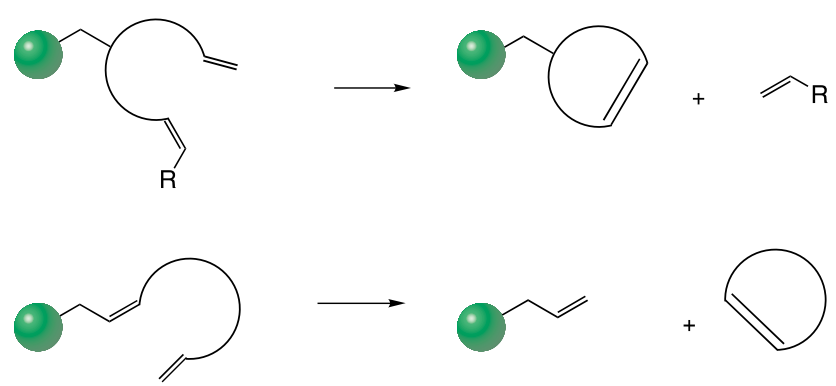

Scheme $6^{16}$

Subsequently other traceless silicon linkers have been reported some of which are easier to synthesise and are cleaved under milder conditions than scheme $8,{ }^{19}$ and traceless linkers utilising Ge and $\mathrm{P}$ have also been utilised. $^{20}$<smiles>NS(=O)(=O)c1ccc(C(=O)NC2CCC3(CC2)OC(=O)c2ccc(OCc4ccc(C(=O)Nc5ccccc5)cc4[N+](=O)[O-])cc2O3)cc1</smiles><smiles>NS(=O)(=O)c1ccc(C(=O)NC2CCC3(CC2)CC(=O)c2ccc(O)cc2O3)cc1</smiles>

Scheme $7^{17}$

Safety catch linkers involve a functional group that is unreactive during synthetic elaboration of the small molecule but is activated by chemical transformation immediately prior to cleavage. This concept was utilised in peptide synthesis ${ }^{21}$ and a recent example is shown in scheme 9 where an aryl thioether is activated by oxidation to a sulfone prior to nucleophilic cleavage with a secondary amine. ${ }^{22}$ 

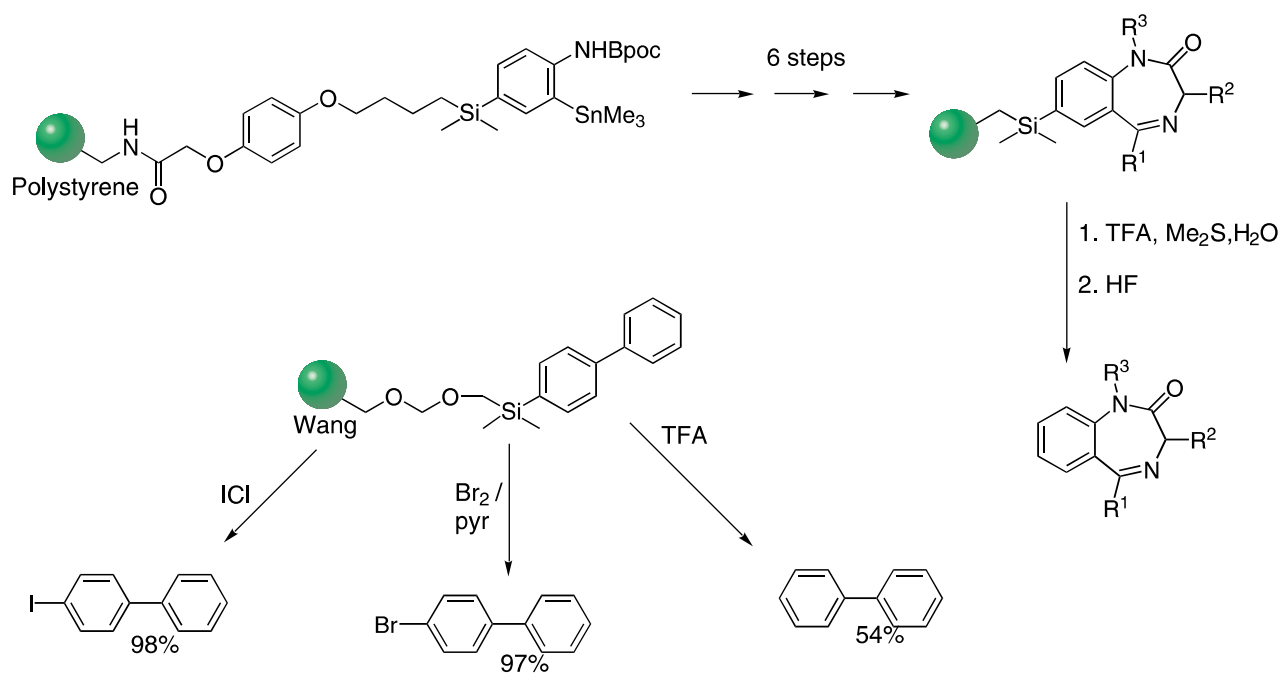

Scheme 8

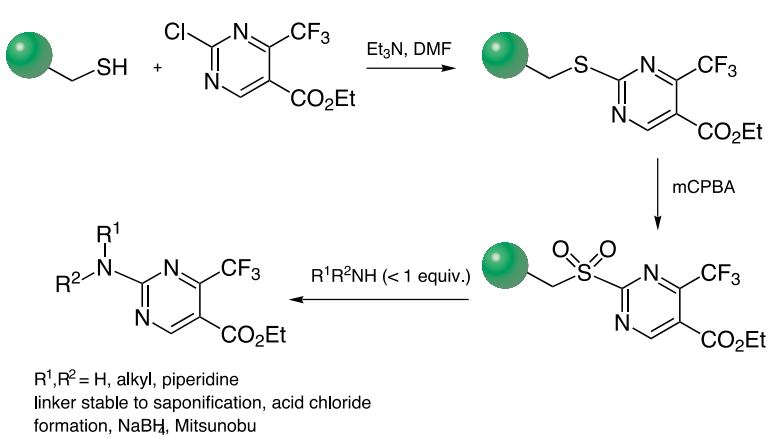

Scheme 9
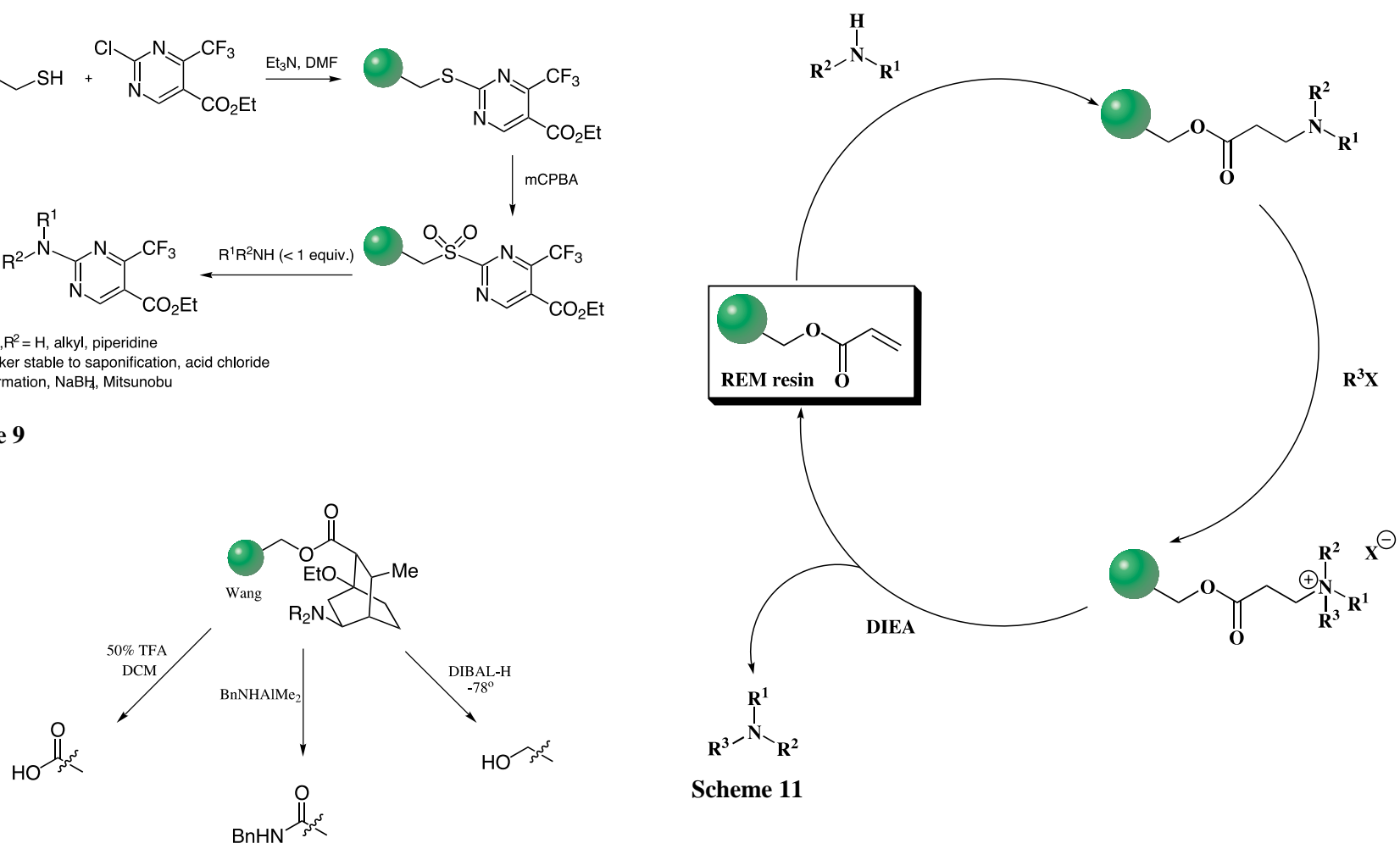

Scheme 11

Scheme 10

A linker may be amenable to cleavage under varying reaction conditions each leading to different products. Scheme 10 shows that a classical ester linker can lead to an acid after hydrolysis or an amide after aminolysis or an alcohol after reductive cleavage. ${ }^{23}$ This strategy may be used to increase the diversity of a compound library during the final step of a solid-phase synthesis.

Another strategy which has emerged is that of designer linkers which are particularly suited for the release of specific functional groups after cleavage. In the two examples shown below classical solution phase reactions are applied in a novel way to solid phase chemistry allowing the synthesis of tertiary (scheme 11$)^{24,25}$ and secondary amines (scheme 12). ${ }^{26}$

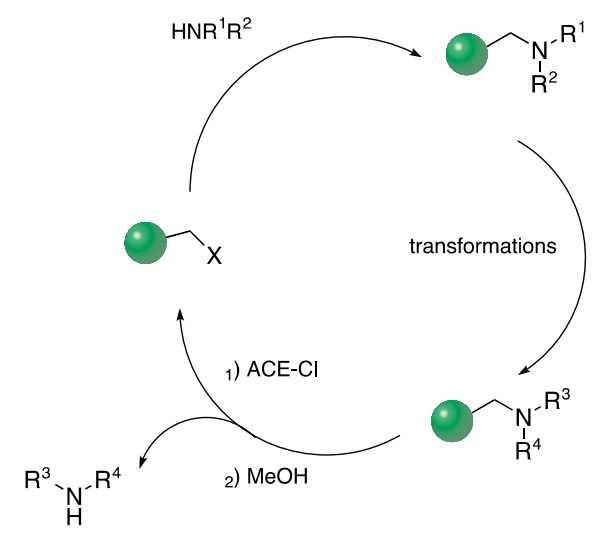

Scheme 12 
The methodology for the synthesis of tertiary amines outlined in scheme 11 is characterised by three stages, i) Michael addition of an amine onto the acrylate (REM) resin, ii) quaternisation of the resin bound tertiary amine which serves the dual purpose of activation and adding an additional building block and iii) cleavage of the product amine via a Hofmann elimination reaction. The REM chemistry described above uses a linker that is regenerated during the cleavage. This has been successfully reused and recycled to produce $>500 \mathrm{mg}$ quantities of simple tertiary amines in good yield and high purity. ${ }^{25}$ This approach offers potential for scale-up and automation. Recently the acrylate group in REM resin has been replaced by a vinyl sulfone which has improved stability to nucleophiles including Grignard reagents. ${ }^{27}$ Debenzylation of tertiary amines by treatment with $\alpha$-chloroethyl chloroformate (ACE$\mathrm{Cl}$ ) is utilised in scheme 12 to liberate a secondary amine from a polymer supported tertiary benzyl amine. The immobilised tertiary amine 3 (scheme 12) is stable towards a wide variety of reaction conditions (99\% TFA; KOBu-t; NaH).

\subsection{Reaction Monitoring ${ }^{28}$}

Once the solid support and synthetic route has been selected, the next problem comes with actually trying to determine if the chemisty is working. In solution we would normally use some form of chromatography as the first monitor (i.e. TLC).

However, with the molecule under reaction tethered to the insoluble support chromatographic monitoring is only possible after cleavage and work up. For many supports this is very labour intensive, and is normally only an option for linker functionalised supports which allow clean and fast release of substrate into a suitable solvent for trace analysis. Non-destructive methods such as $\operatorname{IR}^{29}$ (figure 5) and gel-phase $\mathrm{NMR}^{30}$ are methods of solid phase reaction monitoring which give useful results with standard laboratory instrumentation. The majority of functionalised polystyrene-divinylbenzene supports give very good IR spectra from $\mathrm{KBr}$ discs, although absorption bands from PEG-PS-DVB resins are typically of much lower intensity and are generally less useful. ${ }^{31}$

Fully solvated resins give good quality ${ }^{13} \mathrm{C}$ NMR spectra under standard acquisition conditions and both PS-DVB and PEG-PS-DVB resins give similar quality spectra (see for example figure 3; chemistry Scheme 15). More specialised equipment is necessary to obtain good quality proton spectra and ${ }^{1} \mathrm{H}^{13} \mathrm{C}$ correlation spectra from polymer supported molecules, ${ }^{32}$ although the results can sometimes justify the expense. Mass analysis has also been demonstrated as a useful analytical method for bead analysis by using MALDI-TOF MS. ${ }^{33}$ There are also a range of classical analytical techniques which can give useful information on the progress of solid phase reactions, such as - titration of functional groups (amines, acids, thiols, etc); Elemental analysis; Gravimetric analysis; Colour tests ${ }^{34}$ (Ellman-Thiols, Kaiser-amines, Bromophenol blue basic nitrogen (figure 4), Chloranil - secondary vs. tertiary amine).

\subsection{Experimental Conditions}

Vessels and agitation. Typical glassware used for solution phase synthesis is also suited to solid phase reactions. Disposable fritted polypropylene vessels ${ }^{35}$ are also useful for carrying out solid phase reactions at ambient temperature, although some solvents/reagents will leach plasticiser from the vessel on cleavage of the product from the support. Commercially available glass peptide vessels (Figure 6) can also be used for solid phase synthesis, but are limited in their uses.

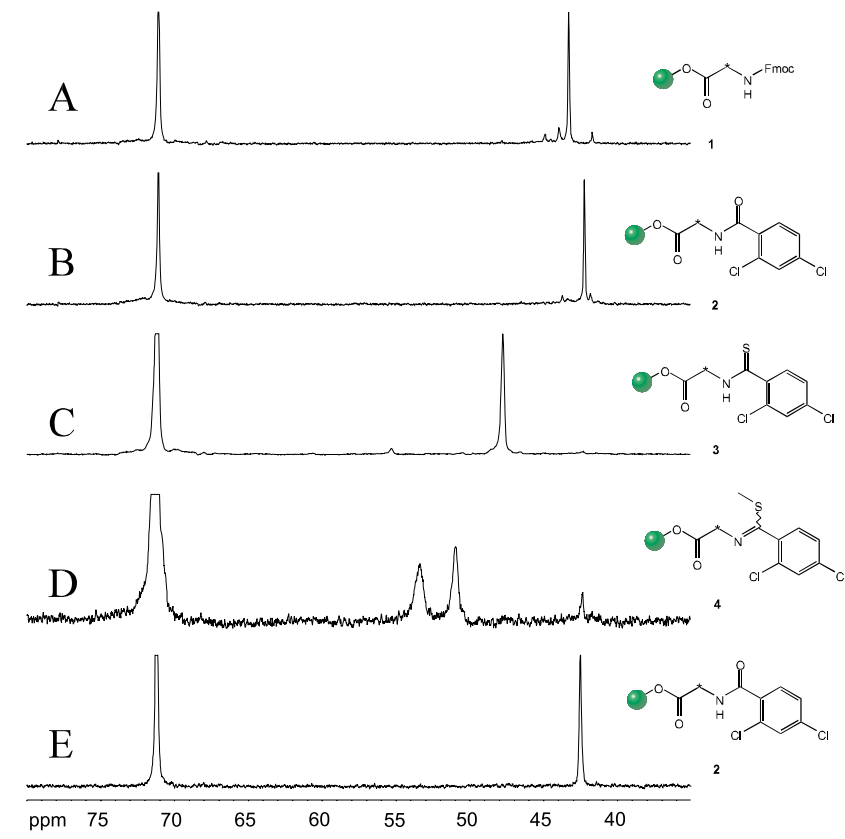

Figure 3. ${ }^{13} \mathrm{C}$ gel-NMR spectra of the reaction products (scheme 15 ) at various stages of the syntheses (the glycine building block was ${ }^{13} \mathrm{C}$ labeled at the $\mathrm{C} \alpha$-carbon. 20-30 $\mathrm{mg}$ of the resin was dispersed in benzene and NMR-spectra were recorded on a Bruker DRX600 spectrometer in approximately 15 minutes.

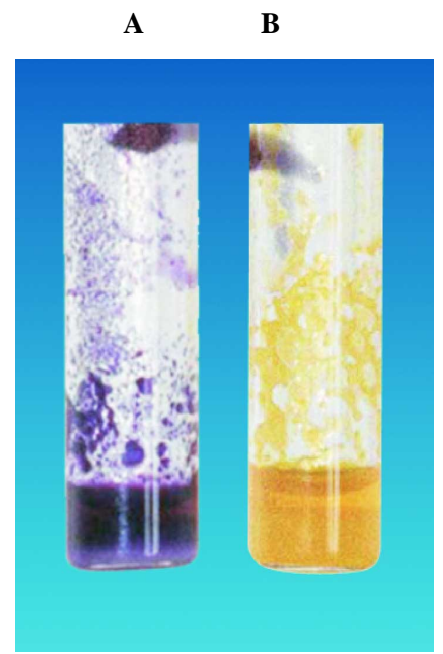

Figure 4. Bromophenol blue test with A) methylamine resin, and B) Wang resin.

Therefore at Organon we developed some of our own glassware for solid phase chemistry (Figure 7 and 8).

Solid supports show varying levels of fragmentation during agitation, and this breakdown is more pronounced at elevated temperatures. Hence, great care must be taken when deciding on methods of agitation. ${ }^{36}$ Resins can successfully be stirred magnetically, but intermittent stirring and very low stirrer speeds must be used to avoid breakdown of beads and subsequent loss of material and/or slow flow rates at the filtration stage. Mechanical stirring (using slow speeds), gas sparging, vortexing and shaking are all much less destructive methods of agitation than magnetic stirring, and sonication for short periods can also be used without detrimental effects with many supports. It is also generally accepted that allowing reactions to stand without agitation 

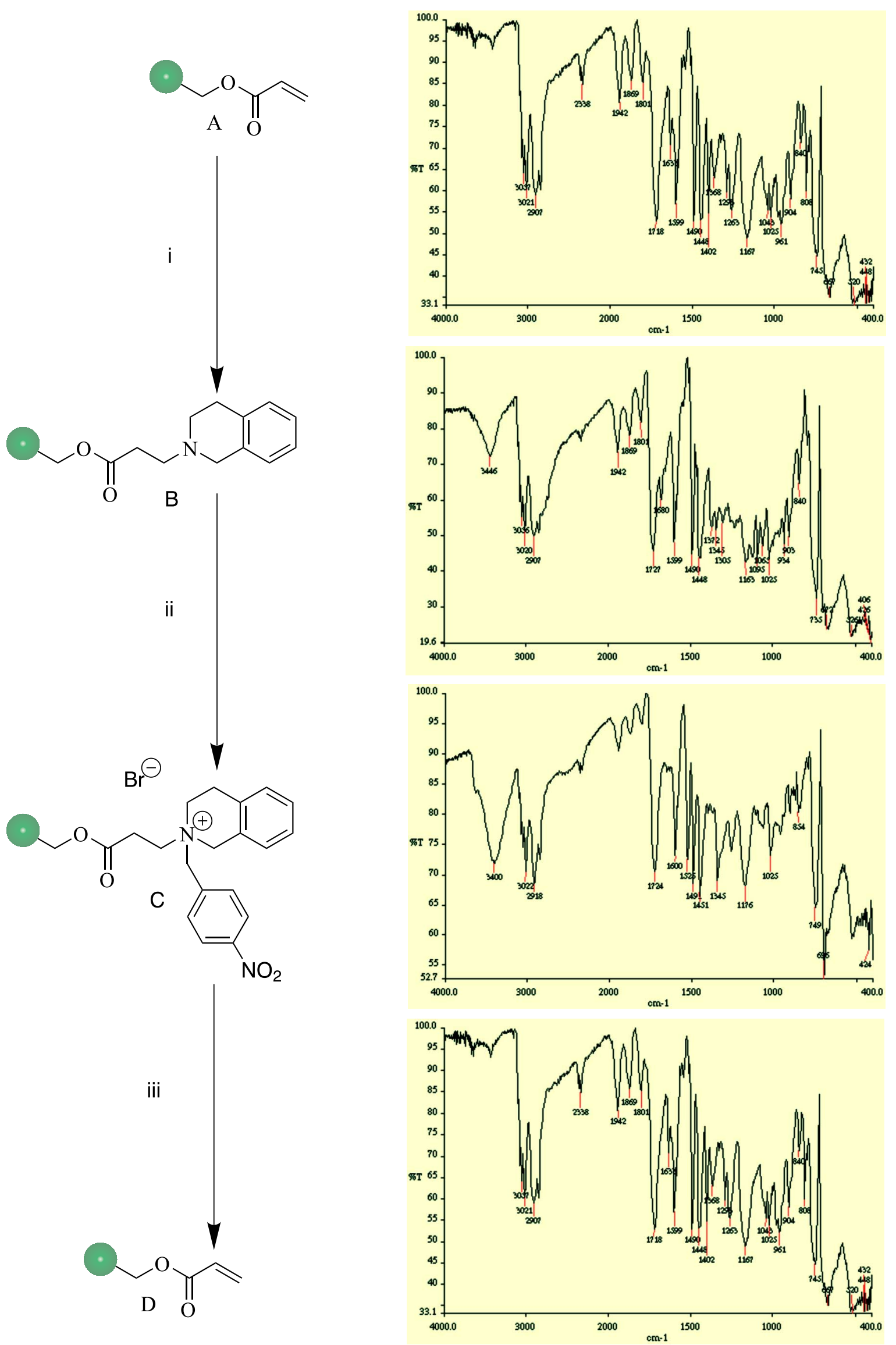

Figure 5. Illustration of IR monitoring of synthetic transformations ofREM resin (see scheme 11$)^{24,25}$ 


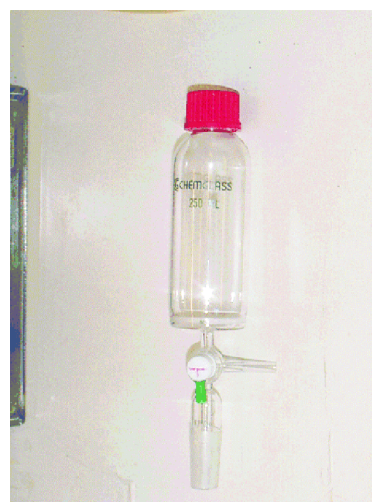

Figure 6
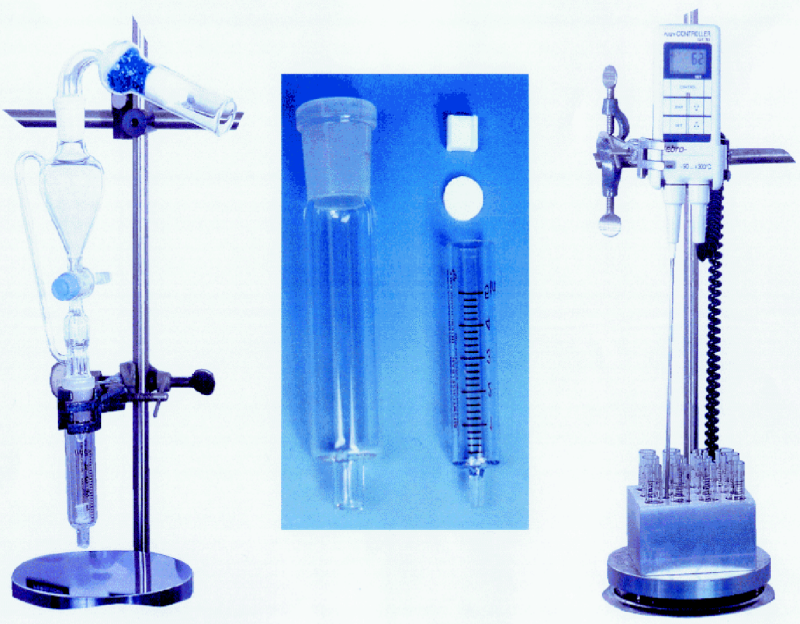

Figure 7. Centre: Reactor (normal glass syringe, disposable frit (PE or PTFE), stirrbar) and glass container. Left: Glass container with reactor and on top a dropingfunnel. Right: 12 reactors is a commercially available heating-block. Stirring and heating can be controlled by standard heating/stirring device.

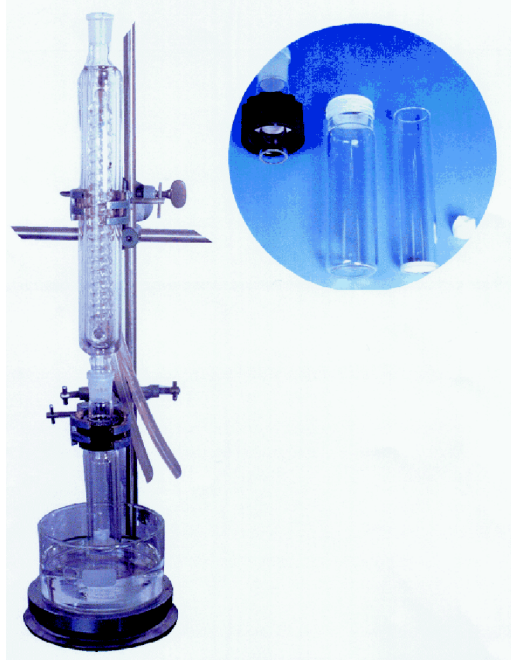

Figure 8. Inset: Reactor with glass frit, container, stirrbar and connector. Main picture: Reactor in container and on top a reflux condensor. gives good results when using swelling solvents and high yielding reactions.

Washing. After each synthetic step and prior to cleavage, the solid support must be exhaustively washed with a range of solvents in order to remove reactants from the resin matrix. It is common practice to alternate swelling solvents, followed by miscible, non-swelling solvents. The final rinse solvent should then fully solvate the resin in preparation for the next step. Resin washing between steps can be carried out by decantation, centrifugation, filtration via canula or funnel, and several suppliers offer fritted glassware suitable for peptide chemistry which can also be used for general room temperature solid phase reactions. Figure 9 shows a commercially available Vacuum manifold for parallel resin washing/product isolation.

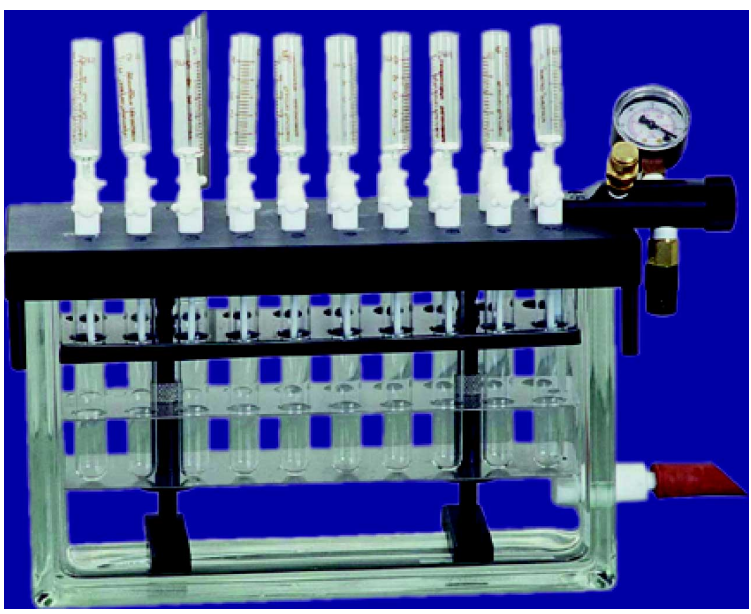

Figure 9. Vacuum manifold for parallel resin washing/product isolation

From solution phase to solid phase

The starting point is the conditions described in the solution-phase chemistry (reagents, solvents, temperature) of the reaction under study. These conditions can then be translated onto solid phase, provided they are amenable to the overall requirements of the resins and linkers as described above. This approach is illustrated by the work of a group from Pharmacia \& Upjohn ${ }^{37}$ who described initial model experiments in solution to study the Pd-catalysed coupling of alkynes to iodoanaline derivatives followed by a cyclisation step resulting in indole and benzofuran moieties. The use of tetramethylguanidine (TMG) as a cosolvent allowed complete conversion. It was found that the solutionphase conditions could be transferred to solid-phase without difficulties (Scheme 13).

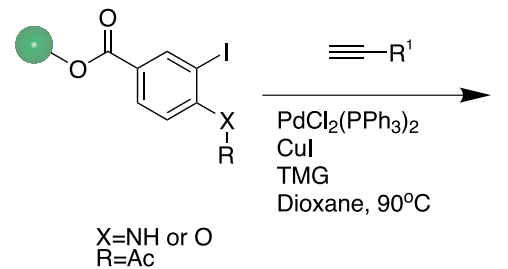<smiles>[R]c1cc2cc(C(=O)OO)ccc2cc1[Tl]</smiles>

$\mathrm{X}=\mathrm{NH}$ or $\mathrm{O}$
$\mathrm{R}=\mathrm{Ac}$

Scheme 13

Another example in which the solution-phase conditions were a good starting point for the transfer to solid-phase has been presented by Y. Cheng et.al. ${ }^{38}$ of Merck Research Laboratories (Scheme 14). 

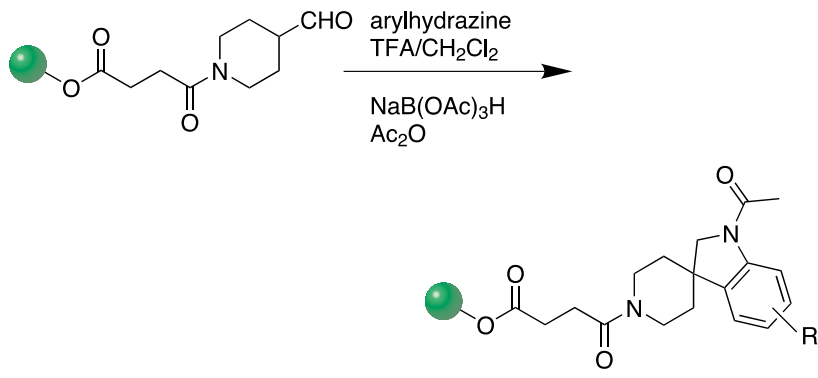

Scheme 14

Various arylhydrazines were studied in the Fischer indole reaction. It was found that TFA as a catalyst and methylene chloride as solvent were crucial in this reaction.

An example in which the direct translation from solution phase to solid phase failed is taken from some recent work carried out at Organon (Scheme 15). The conversion of glycine to oxazoles was studied utilising the published solution phase conditions. ${ }^{39}$ The reactions were monitored by $\mathrm{IR}^{40}$ and ${ }^{13} \mathrm{C}$ gel $\mathrm{nmr}$ spectroscopy (figure 3 ). The transformations proceeded smoothly until the final ring closure step. In this case the conditions described for solution phase chemistry failed to give the anticipated ring closure product when carried out on solid phase. Under these conditions the amide compound (E) was regenerated.
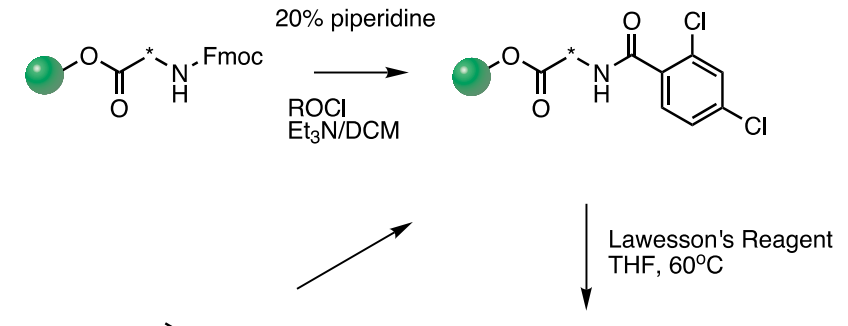

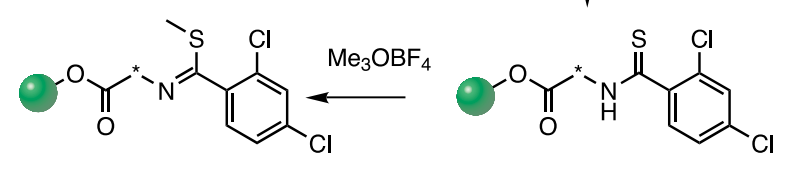

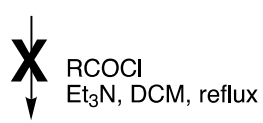<smiles>[R]c1oc(-c2ccc(Cl)cc2Cl)nc1C(=O)OCCO</smiles>

Scheme 15

\subsection{Purification}

Whilst classical methods of purification are equally applicable to the product obtained from a solid phase synthesis, many of these methods are not amenable to parallel purification of multiple samples obtained from this route. As a consequence many innovative approaches to this problem are being developed. Solid phase extraction ${ }^{41}$ allows rapid isolation of multimiligram amounts of compound by utilising a variety of modes (e.g. normal and reverse phase, as well as ion-exchange) and formats (e.g. 96 well plate). A more expensive option is semipreparative HPLC utilising new developments in column technology to cut down run times to less than 10 minutes. Some manufacturers are also offering multiple parallel HPLC systems, and HPLC with mass spectrometry directed fraction collection. Both of which will have a major impact in the way the products from a solid phase route are isolated in the near future.

\subsection{Automation}

One of the main advantages of solid phase chemistry is its amenability to automation and hence synthesis of compound libraries. However, this is usually only possible after the experimental conditions have been optimised and trial reactions have been performed to determine the variety of reagents (building blocks) that can be appropriately utilised. Frequently, it takes several months of experimental work to turn an initially reported solid phase synthesis into a route suitable for library production.

\section{Optimisation and scope determination}

Optimisation is aimed towards high yielding, reliable and clean reactions by varying solvents, reagents, reagent concentrations and temperature. Application of a synthesis robot may expedite this study. Monitoring of the reactions (vide supra) is important for a rapid feedback in this optimisation procedure.

R.M. Valerio $e t a l^{42}$ of Chiron Mimotopes described the optimisation of the Mitsunobu chemistry carried out on Multipin synthesis for the preparation of ethers (Scheme 16).

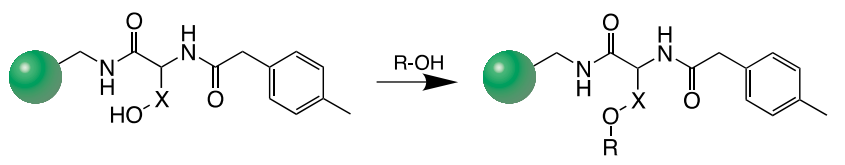

$\mathrm{X}-\mathrm{OH}=$

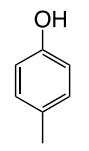

a

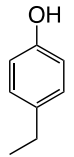

b

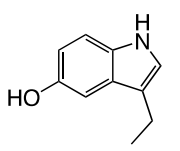

\section{Scheme 16}

In the initial experiments, a number of different variables were investigated simultaneously on model phenolic structure a. These include solvents $(\mathrm{x} 6)$, temperature $(\mathrm{x} 3)$, reaction time (1-4 days), reactant concentrations, types of phosphine (x3), presence of base and type of alcohol. The optimal conditions described are;

- $\quad$ THF as solvent

- temperature is $37^{\circ} \mathrm{C}$

- reaction time is between 48-96 hours

- reactant concentrations are $0.15 \mathrm{M}$ (phosphine, DEAD and alcohol) and $0.45 \mathrm{M}$ (base)

- optimal phosphine is $\mathrm{PPh}_{3}$

- $\quad$ addition of TEA improves conversion

Thereafter these optimum conditions have been tested on all three model phenolic systems a-c with a range of alcohols with success. 
C.A. Willoughby et $a l^{43}$ of Merck Research Laboratories described the optimisation of the reaction of polymer-bound aryl bromides with amines in the presence of a palladium catalyst (see Scheme 17).

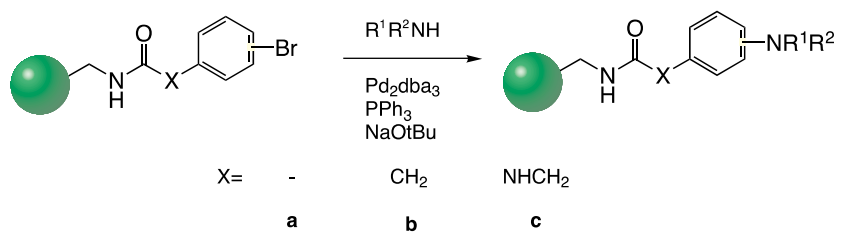

\section{Scheme 17}

After screening several phosphines and solvents (the number of experiments has not been mentioned) it was found that for cyclic amines, anilines and secondary amines the optimal Pd-ligand was $\mathrm{P}(\mathrm{o}-$ tolyl $)_{3}$ and the solvent of choice was dioxane. For the synthesis of primary amines the biphosphine ligand BINAP was the best choice. With the appropriate ligand selection, this chemistry can be successfully used for coupling of primary amines, secondary amines (cyclic and acyclic) and anilines.

H. Künzer et $a l^{44}$ of Schering AG reported the optimisation of the Baylis Hillman reaction of a set of aldehydes to polymer-bound acrylic acid followed by the Michael additions of secondary amines (see Scheme 18).
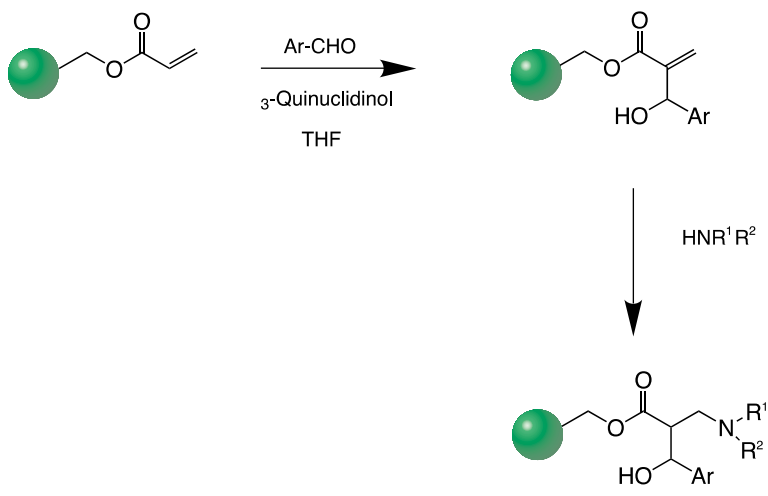

Scheme 18

In a single run, 18 discrete resin-bound combinations were automatically assembled in triplicate on a 60-well reactor block (Syro) from 6 aldehydes and 3 secondary amines.

\section{Equipment}

In Tetrahedron Report No $418^{5}$ we included a table of commercially available equipment for automated, solid-phase organic chemistry in the high price category (above $\$ 125.000$ ). In this review we present a table of commercially available, low budget (below \$30.000) solid-phase synthesis equipment (Table 2). This Table gives only the most elementairy equipment (i.e. synthesis units) while information on extra additions (software, robotics etc.) is given in the footnotes.

\section{Recent examples}

Non-oligomeric natural product synthesis on the solid phase is not a new development, ${ }^{45}$ but recently Nicolaou ${ }^{16}$ has extended the utility of solid phase synthesis within a multistep synthesis of a complex natural product. The solid-phase synthesis of epothilone A (Scheme 19) represents a new development for the total synthesis of natural products and opens the way for the generation of large combinatorial natural product libraries.

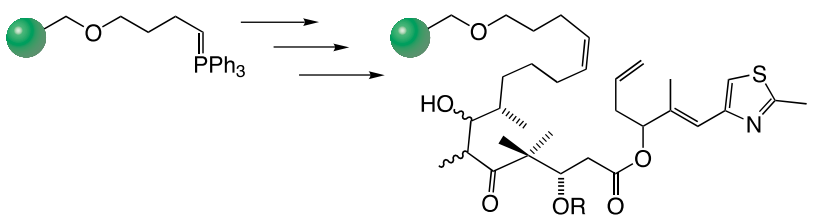<smiles>C/C(=C\c1csc(C)n1)C(CC1OC1CCCC1[C@H](O)C(C)C(=O)C1(C)C)OC(=O)C[C@@H](C)O</smiles><smiles>C/C(=C\c1csc(C)n1)C(C/C=C\CCCC1[C@H](O)C(C)C(=O)[C@H](C)C1(C)C)OC(=O)C[C@H](O)/C(C)=C/c1csc(C)n1</smiles>

Scheme 19

\section{Acknowledgement}

The measurements reported in figures 3 and 5 were made by $\mathrm{Y}$. Diepeveen and L. Orbons, and J. R. Morphy and A. Osprey respectively.

\section{References}

(1) Atherton, E.; Sheppard, R.C. Solid Phase Peptide Synthesis: A Practical Approach; Oxford University: Oxford, 1989.

(2) Gait, J.M. Solid Phase Oligonucleotide Synthesis: A Practical Approach; IRL: Oxford, 1989.

(3) Erickson, B.W.; Merrifield, R.B.In The Proteins, 3rd ed., Vol. 2; Neurath, H.; Hill, R.L., Eds.; Academic: New York, 1976; p 255.

(4) Balkenhöhl,F.; v d BusscheHünnefeld,C; Lansky, A.; Zechel, C. Angew. Chem. Int. Ed. Engl. 1996, 35, 2288

(5) Hermkens, P.H.H.; Ottenheijm, H.C.J.; Rees, D.C. Tetrahedron Report 394, Tetrahedron 1996, 52, 4527-4554 b) Hermkens, P.H.H.; Ottenheijm, H.C.J.; Rees, D.C. Tetrahedron Report 418, Tetrahedron 1997, 53, 5643-5678.

(6) Combinatorial Peptide and Non Peptide Libraries - A Handbook; Jung, G., Ed.; VCH: Weinheim, 1996.

(7) Floyd, C.D.; Lewis, C.N.; Whittaker, M. Chem. Brit. 1996, 32, 31.

(8) Jayalekshmy, P.; Mazur, S. J. Am. Chem. Soc., 1976, 98, 6710.

(9) Resins suitable for solid phase synthesis are available from Aldrich, Fluka, Novabiochem, ACT, Argonaut, Polymer Laboratories and Rapp Polymere.

(10) Ellman, J.A.; Virgilio, A.A. J. Am. Chem. Soc., 1994, 116, 11580.

(11) Hiroshige, M.; Hauske, J.R.; Zhou, P. J. Am. Chem. Soc., 1995, $117,11590$.

(12) Merrifield, R.B. J. Am. Chem. Soc., 1963, 85, 2149.

(13) Wang, S.S. J. Am. Chem. Soc., 1973, 95, 1328.

(14) Mergler, M.; Tanner, R.; Gosteli, J.; Grogg, P. Tetrahedron Lett., 1988, 22, 4005.

(15) Gordon, D.W.; Steele, J. Bioorg. Med. Chem. Lett. 1995, 5, 47.

(16) Nicolaou, K.C.; Winssinger, N.; Pastor, J.; Ninkovic, S.; Sarabia, F.; He, Y.; Vourloumis, D.; Yang, Z.; Li, T.; Giannakakou, P.; Hamel, E. Nature 1997, 387, 268-272. van Maarseveen, J.H.; den Hartog, J.A.J.; Engelen, V.; Finner, E.; Visser, G.; Kruse, C.G. Tetrahedron Lett., 1996, 37, 8249-8252. Peters, J-U.; Blechert, S. Synlett 1997, 348-350 
Table 2. Commercially available low-budget synthesis equipment

\begin{tabular}{|c|c|c|c|c|c|c|c|c|}
\hline Company & Name & Price & Reactor info & mixing & $\begin{array}{l}\text { temp. } \\
\text { range }\end{array}$ & $\begin{array}{l}\text { recovery } \\
\text { of solvents }\end{array}$ & $\begin{array}{c}\text { filtration } \\
\text { system }\end{array}$ & comments \\
\hline $\begin{array}{l}\text { Charybdis } \\
\text { Technologies } \\
\text { Inc }^{\mathrm{a}}\end{array}$ & $\begin{array}{l}\text { Calypso } \\
\text { System }^{\text {TM }}\end{array}$ & $\begin{array}{c}\text { Basic Kit } \$ 6,100 \\
\text { Reaction Block } \\
\$ 1,800\end{array}$ & $\begin{array}{l}\text { - } 96 \text { well filtration } \\
\text { microtiter plate ( } 8 \text { by } \\
12 \text { orthogonal array) } \\
\text { - optional are } 24 \text { and } 48 \\
\text { well models } \\
\text { - } 2 \text { ml volume, glass } \\
\text { wells } \\
\end{array}$ & $\begin{array}{l}\text { 3-axis, } \\
\text { micro-orbit } \\
\text { platform } \\
\text { agitation }\end{array}$ & $\begin{array}{l}-50 \text { to } \\
140^{\circ} \mathrm{C}\end{array}$ & $\begin{array}{l}\text { yes } \\
\text { closed } \\
\text { system; } \\
\text { pressure } \\
\text { and/or } \\
\text { vacuum }\end{array}$ & $\begin{array}{l}\text { in-situ } \\
\text { pressure } \\
\text { and/or } \\
\text { vacuum }\end{array}$ & $\begin{array}{l}\text { - solid and solution phase } \\
\text { - modular approach } \\
\text { - parallel synthesis } \\
\text { - full chemical compatibility } \\
\text { - closed system } \\
\text { - atmospheric control; } 0-30 \text { psi gas pressure } \\
\left(\mathrm{N}_{2}, \mathrm{Ar}, \mathrm{H}_{2}, \mathrm{CO}_{2}, \mathrm{CO} \text { etc.) }\right.\end{array}$ \\
\hline Rapp Polymere & $\begin{array}{c}\text { APOS } \\
1200\end{array}$ & $\begin{array}{c}\$ 13,575^{\mathrm{c}} \\
\text { DEM } 21,690\end{array}$ & $\begin{array}{l}\text { - } 12 \text { positions } \\
\text { - glass reactors } \\
\text {-2-3 ml solvent } \\
\text { - } 200 \mathrm{mg} \text { resin }\end{array}$ & gas bubbles & $\begin{array}{l}-60 \text { to } \\
150^{\circ} \mathrm{C}\end{array}$ & $\begin{array}{c}\text { yes } \\
\text { reflux }\end{array}$ & $\begin{array}{l}\text { in-situ } \\
\text { vacuum } \\
\text { glass filter }\end{array}$ & $\begin{array}{l}\text { - solid and solution phase } \\
\text { - modular approach } \\
\text { - open system } \\
\text { - full chemical compatibility }\end{array}$ \\
\hline $\begin{array}{c}\text { Rapp } \\
\text { Polymere }\end{array}$ & SYREM & $\begin{array}{c}\$ 1,850 \\
\text { DEM } 2,990\end{array}$ & $\begin{array}{l}\text { - } 96 \text { well microtiter } \\
\text { plate } \\
\text { - glass reactors } \\
\text { - } 150 \text { and } 450 \mu \mathrm{l}\end{array}$ & $\begin{array}{l}\text { platform } \\
\text { agitation }\end{array}$ & RT & no & $\begin{array}{l}\text { in-situ } \\
\text { vacuum } \\
\text { glass filters }\end{array}$ & $\begin{array}{l}\text { - solid and solution phase } \\
\text { - modular approach } \\
\text { - open system } \\
\text { - parallel synthesis }\end{array}$ \\
\hline $\begin{array}{l}\text { Chemglass and } \\
\text { Diversomer } \\
\text { Technologies }\end{array}$ & $\begin{array}{c}8-100 \\
\text { Synthesizer }\end{array}$ & $\$ 795^{\mathrm{d} . \mathrm{c}, \mathrm{f}}$ & $\begin{array}{l}\text { - } 8 \text { positions } \\
\text { - glass reactors } \\
\text { - } 6 \text { or } 10 \mathrm{ml} \text { volume } \\
\text { - } 100 \mathrm{mg} \text { resin }\end{array}$ & $\begin{array}{l}\text { stirbars or } \\
\text { platform } \\
\text { agitation }\end{array}$ & $\begin{array}{l}-60 \text { to } \\
200^{\circ} \mathrm{C}\end{array}$ & $\begin{array}{l}\text { yes } \\
\text { reflux }\end{array}$ & $\begin{array}{l}\text { in-situ } \\
\text { gravity } \\
\text { glass filter }\end{array}$ & $\begin{array}{l}\text { - solid and solution phase } \\
\text { - modular approach } \\
\text { - parallel synthesis } \\
\text { - full chemical compatibility }\end{array}$ \\
\hline $\begin{array}{l}\text { Chemglass and } \\
\text { Diversomer } \\
\text { Technologies }\end{array}$ & $\begin{array}{c}40-100 \\
\text { Synthesizer }\end{array}$ & $\$ 1,795^{\mathrm{d} e . f}$ & $\begin{array}{l}\text { - } 40 \text { positions } \\
\text { - glass reactors } \\
\text { - } 6 \text { or } 10 \mathrm{ml} \text { volume } \\
\text { - } 100 \mathrm{mg} \text { resin }\end{array}$ & $\begin{array}{l}\text { stirbars or } \\
\text { platform } \\
\text { agitation }\end{array}$ & $\begin{array}{l}-60 \text { to } \\
200^{\circ} \mathrm{C}\end{array}$ & $\begin{array}{l}\text { yes } \\
\text { reflux }\end{array}$ & $\begin{array}{l}\text { in-situ } \\
\text { gravity } \\
\text { glass filter }\end{array}$ & $\begin{array}{l}\text { - solid and solution phase } \\
\text { - modular approach } \\
\text { - parallel synthesis } \\
\text { - full chemical compatibility }\end{array}$ \\
\hline $\begin{array}{c}\text { Chemglass and } \\
\text { Diversomer } \\
\text { Technologies }\end{array}$ & $\begin{array}{c}10-800 \\
\text { Synthesizer }\end{array}$ & $\$ 1,350^{\text {de }, f}$ & $\begin{array}{l}\text { - } 10 \text { positions } \\
\text { - glass reactors } \\
\text { - } 30 \mathrm{ml} \text { volume } \\
\text { - } 800 \mathrm{mg} \text { resin }\end{array}$ & $\begin{array}{l}\text { stirbars or } \\
\text { platform } \\
\text { agitation }\end{array}$ & $\begin{array}{l}-60 \text { to } \\
200^{\circ} \mathrm{C}\end{array}$ & $\begin{array}{l}\text { yes } \\
\text { reflux }\end{array}$ & $\begin{array}{l}\text { in-situ } \\
\text { gravity } \\
\text { glass filter }\end{array}$ & $\begin{array}{l}\text { - solid and solution phase } \\
\text { - modular approach } \\
\text { - parallel synthesis } \\
\text { - full chemical compatibility }\end{array}$ \\
\hline MultiSynTech & $\begin{array}{l}\text { SYRO } \\
\text { Manuell } \\
\text { System } \\
\text { (SMS) }\end{array}$ & DEM $55,000^{\mathrm{g}}$ & $\begin{array}{l}\text { - } 40,60 \text { or } 96 \text { positions } \\
\text { - glass reactors } \\
\text { - } 2,5 \text { or } 10 \mathrm{ml} \text { volume } \\
\text { - } 10-200 \mathrm{mg} \text { resin }\end{array}$ & stirbars & $\begin{array}{l}-30 \text { to } \\
150^{\circ} \mathrm{C}\end{array}$ & $\begin{array}{l}\text { yes } \\
\text { reflux }\end{array}$ & $\begin{array}{c}\text { in-situ } \\
\text { vacuum } \\
\text { glas filters }\end{array}$ & $\begin{array}{l}\text { - solid phase } \\
\text { - parallel synthesis } \\
\text { - full chemical compatibility }\end{array}$ \\
\hline CSPS & Multiblock $^{\mathrm{h}}$ & $\$ 2,390$ & $\begin{array}{l}\text { - } 42 \text { positions } \\
\text { - syringes } \\
\text { - } 2 \mathrm{ml} \text { volume } \\
\text { - } 10-200 \mathrm{mg} \text { resin }\end{array}$ & $\begin{array}{l}\text { platform } \\
\text { agitation }\end{array}$ & $\begin{array}{l}-20 \text { to } \\
70^{\circ} \mathrm{C}\end{array}$ & no & $\begin{array}{l}\text { in-situ } \\
\text { vacuum }\end{array}$ & $\begin{array}{l}\text { - solid phase } \\
\text { - parallel and split/pool } \\
\text { - modular approach }\end{array}$ \\
\hline BOHDAN & $\begin{array}{l}\text { Solid-Phase } \\
\text { Synthesis } \\
\text { Block } \\
\text { Model: } \\
\text { SPS }\end{array}$ & $\begin{array}{c}\$ 24,500 \text { to } \\
\$ 34,500\end{array}$ & $\begin{array}{l}\text { - } 48 \text { positions } \\
\text { - } 18 \times 125 \mathrm{~mm} \\
\text { - glass reactors } \\
\text { - sintered glass frit }\end{array}$ & $\begin{array}{l}\text { orbital } \\
\text { shaking }+ \\
\text { argon } \\
\text { bubbling } \\
\text { through frit } \\
+ \text { argon } \\
\text { bubbling } \\
\text { through } \\
\text { cannula }\end{array}$ & $\begin{array}{l}-40 \text { to } \\
200^{\circ} \mathrm{C}\end{array}$ & $\begin{array}{l}\text { yes } \\
\text { reflux and } \\
\text { pressure up } \\
\text { to } 2 \text { bars }\end{array}$ & $\begin{array}{l}\text { in-situ } \\
\text { bottom } \\
\text { filtration } \\
\text { through frit }\end{array}$ & $\begin{array}{l}\text { - solid phase and solution phase, parallel } \\
\text { synthesis } \\
\text { - modular approach } \\
\text { - full chemical comatibility } \\
\text { - delivery of argon by } 3 \text { methods to each vessel }\end{array}$ \\
\hline BOHDAN & $\begin{array}{l}\text { RAM } \\
\text { Synthesizer } \\
\text { TM } \\
\text { Model:AR } \\
\text { S } 300\end{array}$ & $\$ 18,900$ & $\begin{array}{l}\text { - } 48 \text { positions } \\
\text { - } 16 \times 125 \mathrm{~mm} \text { glass } \\
\text { reactors } \\
\text { - internal filter stick }\end{array}$ & $\begin{array}{l}\text { Orbital } \\
\text { shaking }+ \\
\text { argon } \\
\text { bubbling } \\
\text { through } \\
\text { cannula }\end{array}$ & $\begin{array}{l}-40 \text { to } \\
200^{\circ} \mathrm{c}\end{array}$ & $\begin{array}{l}\text { Reflux and } \\
\text { pressure up } \\
\text { to } 2 \text { bars }\end{array}$ & $\begin{array}{l}\text { in-situ } \\
\text { Top } \\
\text { filtration }\end{array}$ & $\begin{array}{l}\text { - Solid phase chemistry } \\
\text { - Microtube }{ }^{\mathrm{TM}} \text { reactors } \\
\text { - solution phase } \\
\text { - parallel synthesis } \\
\text { - split/pool } \\
\text { - full chemical compatibility } \\
\text { - delivery of argon by } 2 \text { methods to each vessel }\end{array}$ \\
\hline $\begin{array}{c}\text { Chiron } \\
\text { Technologies }\end{array}$ & $\begin{array}{l}\text { SynPhase }^{\mathrm{T}} \\
{ }^{\mathrm{M}} \text { Crowns } \\
\text { Multipin }^{\mathrm{TM}} \\
\text { System } \\
\text { Transtems }\end{array}$ & $\begin{array}{l}\text { currently not } \\
\text { available }\end{array}$ & $\begin{array}{l}\text { - } 96 \text { Crowns per holder } \\
\text { in the Multipin format } \\
\text { - Multiple holders are } \\
\text { used in parallel } \\
\text { - Can be used in } \\
\text { standard laboratory } \\
\text { glassware } \\
\text { - Three types of crowns } \\
\text { (Q-, I- and P-Series) } \\
\text { - wide range of loadings } \\
\text { (between 1-46 } \\
\mu \text { Mol/crown) and } 3 \\
\text { different grafted } \\
\text { surfaces }\end{array}$ & $\begin{array}{l}\text { platform } \\
\text { agitation } \\
\text { or } \\
\text { sonification }\end{array}$ & $\begin{array}{l}20 \text { to } \\
80^{\circ} \mathrm{C}\end{array}$ & $\begin{array}{l}\text { Multipin } \\
\text { format; } \\
\text { higher } \\
\text { boiling } \\
\text { solvents } \\
\text { may be } \\
\text { employed }\end{array}$ & not required & $\begin{array}{l}\text { - Crowns can be used as a replacement for } \\
\text { resins } \\
\text { - parallel synthesis and split/pool } \\
\text { - single compounds or mixtures } \\
\text { - Multipin can be augmented by the use of } \\
\text { Transtems which allows radio frequency } \\
\text { tracking of individual crowns } \\
\text { - amenable for robotic sorting }\end{array}$ \\
\hline
\end{tabular}

(17) Burbaum, J. J.; Ohlmeyer, M. H. J.; Reader, J. C.; Henderson, I.; Dillard, L. W.; Li, G.; Randle, T. L.; Sigal, N.H.; Chelsky, D.; Baldwin, J. J. Proc. Natl. Acad. Sci. USA, 1995, 92, 6027.

(18) Plunkett, M.J.; Ellman, J.A. J. Org. Chem., 1995, 60, 6007.
(19) Han, Y.; Walker, S.D.; Young, R.N. Tetrahedron Lett., 1996, 37, 2703. see also Newlander, K. A.; Chenera, B.; Veber, D. F.; Yim, N. C. F.; Moore, M. L. J. Org. Chem., 1997, 62, 6726. Woolard, F. X.; Paetsch, J.; Ellman, J. A. J. Org. Chem., 1997, 62, 6102. 
Table 2. (continued)

\begin{tabular}{|c|c|c|c|c|c|c|c|c|}
\hline $\begin{array}{c}\text { Whatman } \\
\text { polyfiltronics }\end{array}$ & $\begin{array}{l}\text { PolyWhat } \\
\text { Kitsi }^{i}\end{array}$ & $\begin{array}{c}\text { Kit001 DEM } \\
4,800 \\
\text { Kit } 002 \text { DEM } \\
6,150 \\
\text { Kit } 003 \text { DEM } \\
4,900 \\
\text { Kit } 004 \text { DEM } \\
9,600 \\
\end{array}$ & $\begin{array}{l}\text { - } 96 \text { well microtiter } \\
\text { plate } \\
\text { - MultiCHEM or } \\
\text { polypropylene } \\
\text { material } \\
\text { - Polykryptonite } \\
\text { membrane } \\
\text { - } 2 \text { ml chamber }\end{array}$ & $\begin{array}{l}\text { Kit } 001-003 \\
\text { platform } \\
\text { agitation } \\
\text { Kit } 004 \\
\text { mixing by } \\
\text { inert gas }\end{array}$ & $\begin{array}{l}-80 \text { to } \\
140^{\circ} \mathrm{C}\end{array}$ & $\begin{array}{c}\text { yes } \\
\text { Kit } 002- \\
004 \\
\text { by pressure } \\
\text { CombiCla } \\
\text { mp }\end{array}$ & $\begin{array}{l}\text { in-situ } \\
\text { bottom } \\
\text { filtration } \\
\text { through } \\
\text { membrane }\end{array}$ & $\begin{array}{l}\text { - solid and solution phase } \\
\text { - modular approach } \\
\text { - semi-closed system } \\
\text { - parallel synthesis } \\
\text { - partial chemical compatibility }\end{array}$ \\
\hline $\begin{array}{l}\text { Robbins } \\
\text { Scientific }\end{array}$ & $\begin{array}{l}\text { Flexchem } \\
\text { Organic } \\
\text { Synthesis } \\
\text { system }\end{array}$ & $\$ 1830^{k}$ & $\begin{array}{l}\text { - } 96 \text { and } 48 \text { chamber } \\
\text { reaction block } \\
\text { - polypropylene } \\
\text { - polyethylene frit } \\
\text { - disposable } \\
\text { - } 2 \mathrm{ml} \text { ( } 96 \text { well) and } 5 \mathrm{ml} \\
\text { (48 well) } \\
\text { - top and bottom sealed } \\
\text { independently }\end{array}$ & $\begin{array}{l}\text { platform } \\
\text { agitation } \\
\text { or with } \\
\text { FlexChem } \\
\text { Rotating } \\
\text { Incubator }\end{array}$ & $\begin{array}{l}\text { FlexChe } \\
\quad \mathrm{m} \\
\text { Rotating } \\
\text { Incubator } \\
\text { to } 100^{\circ} \mathrm{C}\end{array}$ & $\begin{array}{c}\text { yes } \\
\text { by pressure }\end{array}$ & $\begin{array}{l}\text { in-situ } \\
\text { bottom } \\
\text { filtration } \\
\text { through } \\
\text { filter } \\
\text { vacuum }\end{array}$ & $\begin{array}{l}\text { - solid and solution phase } \\
\text { - modular approach } \\
\text { - semi-closed system } \\
\text { - parallel synthesis } \\
\text { - compatible in nearly every solvent tested }\end{array}$ \\
\hline
\end{tabular}

a) For detailed description see: http//www.charbybtech.com

b) Basic kit: Reaction Block, 96 well; 96-well Multi-Temp.Reactor, Filtration; 96 well gas manifold, vacuum manifold

c) Price of smallest stand alone unit. (Price of system incl.;. extra reaction unit, pipett unit, temp. control, PC and software $\$ 50,875$ ).

d) Price excluding glassware.

e) DTI 2000 series (software, agitator, temperature controler, synthesizers, heater units, glassware, aluminium blocks) between $\$ 15,000$ to $\$ 49,000$ depending upon the options. f) DTI 3000 series (DTI 2000 , liquid handling robot, valve, racks, wash station, cup, needles) $\$ 95,000$ to $\$ 129,000$ depending upon options. g) Extra options are; Temp. range -60 to $150^{\circ} \mathrm{C}$ and in-situ cleavage (DEM 78,000 )

h) For detailed description see http://www. $5 z$.com/csps

i) For detailed description see http://www.polyfiltronics.com/polywhat.html

j) For detailed description see http://www.robsci.com/hitsyn.html

k) Price of smallest stand alone unit. (Price of system incl.;. FlexChem Rotating Incubator extra $\$ 12,500$ ). Prices outside U.S. will be higher.

1) With optional automated washing $\$ 31.500$.

(20) Hughes, I. Tetrahedron Lett.,1996, 37, 7595. Bunin, B.A.; Plunkett, M.J.; Ellman, J.A. In Combinatorial Peptide and Non Peptide Libraries - A Handbook; Jung, G., Ed.; VCH: Weinheim, 1996; p405.

(21) Kenner G.W.; McDermott, J.R.; Sheppard, R.C. J. Chem. Soc. Chem. Commun. 1971, 636, 637.

(22) Gayo, L.M.; Suto, M.J. Tetrahedron Lett. 1997, 38, 211. Obrecht, D.; Abrecht, C.; Grieder, A.; Villalgordo, J. M. Helv. Chim. Acta, 1997, 80, 65 .

(23) Ley, S.V.; Mynett, D.M.; Koot, W-J.Synlett 1995, 1017.

(24) Morphy, J. R.; Rankovic, Z.; Rees, D. C. Tetrahedron Lett. 1996, 37, 3209.

(25) Brown, A.R.; Rees, D.C.; Rankovic, Z.; Morphy, J. R. J. Am. Chem. Soc.,1997, 1 19, 3288.

(26) Conti, P.; Dermont, D.; Cals, J.; Ottenheijm, H.C.J.; Leysen, D. Tetrahedron Lett., 1997, 38, 2915.

(27) Kroll, F. E. K.; Morphy, R.; Rees, D.; Gani, D. Tetrahedron Lett. 1997, 38, 8573. Heinonen, P.; Lönnberg, H. Tetrahedron Lett. 1997, 38, 8569 .

(28) Egner, B.J.; Bradley, M. Drug Discovery Today 1997, 2, 102.

(29) Hauske, J.R.; Dorff, P. Tetrahedron Lett., 1995, 36, 1589.

(30) Look, G.C.; Holmes, C.P.; Chinn, J.P.; Galop, M.A. J. Org. Chem., 1994, 59, 7588.

(31) Combinatorial Peptide and Non Peptide Libraries - A Handbook; Jung, G., Ed.; VCH: Weinheim, 1996.
(32) Seeberger, P.H.; Beebe, X.; Sukenick, G. D.; Pochapsky, S. J.; Danishefsky, S. J. Angew. Chem. Int. Ed. Engl. 1997, 36, 491.

(33) Egner, B.J.; Langley, G.D.; Bradley, M. J. Org. Chem. 1995, 60, 2652.

(34) Representative resin tests are listed within the 1997/98 Novabiochem Catalogue \& Peptide Synthesis Handbook Synthesis Notes S38.

(35) Available from Bio-Rad Laboratories Ltd. Hemel Hempstead, HP2 7TD, UK. See also reference 7.

(36) Li, W.; Yan, B. Tetrahedron Lett. 1997, 38, 6485.

(37) Fagnola, M.C.; Candiani, I.; Visentin, G.; Cabri, W.; Zarini, F.; Mongelli N.; Bedeschi A. Tetrahedron Lett., 1997, 38, 2307.

(38) Cheng, Y.; Chapman, K.T. Tetrahedron Lett., 1997, 38, 1497.

(39) Yokoyama, M.; Menjo, Y.; Watanabe, M.; Togo, H. Synthesis 1994, 1467.

(40) Deben, I. E. A.; Vanwijk, T. H. M.; Vandoornum, E. M.; Hermkens, P. H. H.; Kellenbach, E. R.; F. Mikrochimica Acta 1997, 245.

(41) Siegel, M. G.; Hahn, P. J.; Dressman, B. A.; Fritz, J. E.; Grunwell, J. R.; Kaldor, S. W. Tetrahedron Lett., 1997, 38, 3357.

(42) Valerio, R.M.; Bray, A.M.; Patsiouras, H. Tetrahedron Lett., 1997, $38,3019$.

(43) Willoughby, C.A.; Chapman, K.T. Tetrahedron Lett., 1996, 37, 7181.

(44) Prien, O.; Rölfing, K.; Thiel, M.; Künzer, H. Synlett 1997, 325.

(45) Leznoff, C.C. Acc. Chem. Res., 1978, 11, 327. 